\title{
Estrogenic Effect of Bambusa arundinacea, Trichosanthes dioica and Punica granatum on Rats
}

\begin{abstract}
Background: Phytoestrogens have recently become a hot topic among scientists. Phytoestrogens' estrogen-like properties have led to their widespread use in the reproductive system. The aim of this research was to see whether the ethanolic extract of Bambusa arundinaceae, Trichosanthes dioica and Punica granatum had any estrogenic activity in female wistar rats.

Methods: In female wistar rats, the estrogenic effect was studied using a uterotropic assay, vaginal cytology and vaginal opening. In ovariectomized immature and mature female wistar rats, a $400 \mathrm{mg} / \mathrm{kg}$ body weight (b.w.) dose of ethanolic extract of Bambusa arundinaceae, Trichosanthes dioica and Punica granatum was given.

Result: When compared to ovariectomized control rats, the uterine wet weight increased significantly. The estrogen-treated rats had only cornified epithelial cells, indicating the existence of oestrogen, as well as $100 \%$ vaginal opening. At $400 \mathrm{mg} / \mathrm{kg}$ b.w., the ethanolic extract of Bambusa arundinaceae, Trichosanthes dioica and Punica granatum demonstrated promising estrogenic activity, as evidenced by uterotropic assays, vaginal opening measurements and histopathological changes. As a result of this research, it's possible to infer that the ethanolic extract of Bambusa arundinaceae, Trichosanthes dioica and Punica granatum play an important role in estrogenic activity in female rats.
\end{abstract}

Key words: Histopathology, Ethanolic extract, Phytoestrogen, Uterotropic assay, Vaginal cytology, Vaginal opening.

\section{INTRODUCTION}

Many plants have been discovered to have estrogenic activity, implying that they contain estrogenic compounds. They contain phytoestrogens, which have biological activity similar to estrogen. The importance of phytoestrogens in human health has been revealed in numerous studies. Phytoestrogens bind to estrogenic receptors in a competitive manner, causing estrogen-responsive genes to be induced (Procházková et al., 2017). 'Bans' is the common name for Bambusa arundinacea (Poaceae). It has anthelmintic, antidiabetic and wound healing effects, as well as antiinflammatory, antiulcer and antifertility properties. Its use in strangury and urinary discharge has been reported in a number of studies (Tripathi et al., 2013; Kumar et al., 2012; Wardhani et al., 2016). Almost every part of the plant has been shown to have medicinal value, such as the root (burnt root) for bleeding gums, the bark for skin eruptions and the leaf as an emmenagogue. Trichosanthes dioica Roxb is an Asian pacific tropical herb. Fruit contains the majority of the medicinal properties (Kumar et al., 2012). It's been used for centuries to treat jaundice and hepatic diseases, as well as swollen liver and spleen (Khatua et al., 2016). In addition, it works as an antipyretic, diuretic, cardiotonic, laxative and antiulcer agent. Experiments have shown that it is successful in promoting fertility (Khan et al., 2020). The pomegranate, Punica granatum, of the Punicae family, has been found to contain estrone, a sex steroid (Peters et al., 1980). Many pharmacological properties, such as anti-microbial, antiparasitic, anti-viral and anti-cancer activity, have been discovered in studies (Mertens-Talcott et al., 2006; Sreeja et al., 2012). Pomegranate juice has been found to contain
1Uttarakhand Technical University, Sudhowala, Dehradun-248 161, Uttarakhand, India.

${ }^{2}$ Sardar Bhagwan Singh University, Balawala, Dehradun-248 161, Uttarakhand, India.

${ }^{3}$ Vivek College of Technical Education, Bijnor-246 701, Uttar Pradesh, India.

Corresponding Author: Akanksha Awasthi, Vivek College of Technical Education, Bijnor-246 701, Uttar Pradesh, India.

Email: akankashaawasthi333@gmail.com

How to cite this article: Awasthi, A., Singh, M.F. and Sharma, S. (2022). Estrogenic Effect of Bambusa arundinacea, Trichosanthes dioica and Punica granatum on Rats. Indian Journal of Animal Research. DOI: 10.18805/IJAR.B-4760.

Submitted: 25-08-2021 Accepted: 27-11-2021 Online: 11-01-2022

flavonoids such as anthocyanins and phenols (Devi et al., 2017). The effects on fertility and estrogen-like effects have also been discovered in experiments (Bekoe et al., 2020).

Therefore, the current research used an uterotropic assay, vaginal cytology and vaginal opening calculation to assess the estrogenic effects of alcoholic extract of Bambusa arundinacea, Trichosanthes dioica and Punica granatum on wistar rats.

\section{MATERIALS AND METHOdS} Study area

This experiment was conducted at Vivek College of Technical Education, Bijnor, Uttar Pradesh during June 2015 to December 2016. 


\section{Experimental animals}

Impuberal female albino wistar rats, 21-day-old, with body weight of $45-50 \mathrm{~g}$, were used. Animals were housed four per cage, in a multiple rat rack. Temperature $\left(21 \pm 2^{\circ} \mathrm{C}\right)$ and humidity $(55 \pm 15 \%)$ were controlled and a $12 \mathrm{~h}$ light/dark cycle was maintained. Water and food were ad libitum. The experiment protocol was approved by the Institutional Animal Ethical Committee (IAEC) according to the regulation of committee for the purpose of control and supervision of experiments on animals (CPCSEA) and ethical norms was strictly followed during all experimental procedure (Ref. No. VCTE/07/2016 CPCSEA). All animals had been acclimatized for three days in the animal room prior the first treatment (Parhizkarsup et al., 2011).

\section{Dose selection}

Doses were selected on the basis of previous toxicity studies carried out for Bambusa arundinaceae (Nilsson et al., 2001) (Table 1), Trichosanthes dioica (Sharangouda et al., 2008) (Table 2) and for Punica granatum (Valadares et al., 2010) (Table 3). The doses selected were $200 \mathrm{mg} / \mathrm{kg}, 300 \mathrm{mg} / \mathrm{kg}$ and $400 \mathrm{mg} / \mathrm{kg}$, p.o.

\section{Preparation of doses}

The plant extracts were prepared in distilled water using carboxymethylcellulose (CMC) as a suspending agent (1\%). The standard drug was also prepared in $\mathrm{CMC}$ and given as suspension to the animals. Control group (Negative control group/Olive oil control group) here through with the help of orogadtric tube $0.2 \mathrm{ml}$ of olive oil was given orally once in a days in between experimental time. Conjugated Equine Estrogen (CEE $0.2 \mathrm{mg} / \mathrm{kg}$ ) was purchased from Pharmacy shop, Bijnor, India. CEE (Wyeth Montreal, Canada), prepared in a dosage (p.o.) of $0.2 \mathrm{mg} / \mathrm{kg}$ by dissolving it in distilled water (Malaivijitnond et al., 2006) and was used as a positive control for comparing with the Test groups. The Plant extracts of Bambusa arundinaceae, Trichosanthes dioica and Punica granatum in different doses $(200 \mathrm{mg} / \mathrm{kg}$, $300 \mathrm{mg} / \mathrm{kg}$ and $400 \mathrm{mg} / \mathrm{kg}$ body weight, orally) was dissolve in $0.2 \mathrm{ml}$ of Olive oil and with the help of Orogastric tube was given by oral route (Goodman and Parker, 2008).

\section{Treatment protocol}

Immature Uterotrophic animals were divided into five groups each containing six animals and one group of normal immature rats. Animals were fasted $18 \mathrm{hrs}$ prior to dosing and 3-4 hours after administration of the plant extracts. The plant extracts were given at a dose of $200 \mathrm{mg} / \mathrm{kg}, 300 \mathrm{mg} /$ $\mathrm{kg}$ and $400 \mathrm{mg} / \mathrm{kg}$ oral routes to the immature female animals for a period of 14 days.

\section{Induction of uterotrophic activity in rats}

Bilaterally ovariectomized, female immature female albino and wistar rats were randomly allotted to different groups. All test substances were administered for 14 days. The animals will be examined twice a day on $4^{\text {th }}$ and $5^{\text {th }}$ day for the presence of the vaginal opening. After noticing the vaginal opening, the vaginal cytology will be observed to examine the cornification of epithelium. Body weight will be recorded on daily basis. On presence of vaginal opening

Table 1: Treatment protocol for estrogenic activity of Bambusa arundinacea using immature uterotropic model.

\begin{tabular}{ll}
\hline Group & Treatment \\
\hline Group I & Animal received normal saline $(1 \mathrm{ml} / \mathrm{kg}, \mathrm{p.o})$. \\
Group II & Animal received ethinyl estradiol as suspension in distilled water $(0.2 \mathrm{mg} / \mathrm{kg}$, body weight orally) \\
Group III & Animal received ethanolic extract of Bambusa arundinaceae leaves $(200 \mathrm{mg} / \mathrm{kg}, \mathrm{p} .0)$. \\
Group IV & Animal received ethanolic extract of Bambusa arundinaceae leaves (300 mg/kg, p.o.) \\
Group V & Animal received ethanolic extract of Bambusa arundinaceae leaves (400 mg/kg, p.o.) \\
\hline
\end{tabular}

Table 2: Treatment protocol for estrogenic activity of Trichosanthes diocio fruit using immature uterotropic model.

\begin{tabular}{ll}
\hline Group & Treatment \\
\hline Group I & Animal received normal saline $(1 \mathrm{ml} / \mathrm{kg}, \mathrm{p} . \mathrm{o})$. \\
Group II & Animal received ethinyl estradiol as suspension in distilled water $(0.2 \mathrm{mg} / \mathrm{kg}$, body weight orally) \\
Group III & Animal received ethanolic extract of Trichosanthes diocio fruit $(200 \mathrm{mg} / \mathrm{kg}, \mathrm{p} .0)$. \\
Group IV & Animal received ethanolic extract of Trichosanthes diocio fruit $(300 \mathrm{mg} / \mathrm{kg}, \mathrm{p} .0)$. \\
Group V & Animal received ethanolic extract of Trichosanthes diocio fruit $(400 \mathrm{mg} / \mathrm{kg}, \mathrm{p} .0)$. \\
\hline
\end{tabular}

Table 3: Treatment protocol for estrogenic activity of Punica granatum seed using immature uterotropic model.

\begin{tabular}{ll}
\hline Group & \multicolumn{1}{c}{ Treatment } \\
\hline Group I & Animal received normal saline $(1 \mathrm{ml} / \mathrm{kg}, \mathrm{p.o})$. \\
Group II & Animal received ethinyl estradiol as suspension in distilled water $(0.2 \mathrm{mg} / \mathrm{kg}$, body weight Orally) \\
Group III & Animal received ethanolic extract of Punica granatum seed $(200 \mathrm{mg} / \mathrm{kg}, \mathrm{p} .0)$. \\
Group IV & Animal received ethanolic extract of Punica granatum seed $(300 \mathrm{mg} / \mathrm{kg}, \mathrm{p} .0)$. \\
Group V & Animal received ethanolic extract of Punica granatum seed $(400 \mathrm{mg} / \mathrm{kg}, \mathrm{p} .0)$. \\
\hline
\end{tabular}


$14^{\text {th }}$ day the animals will be sacrificed by over anesthesia. The uterus was collected and weighed. The percentage of vaginal opening, cornification and relative organ weight were calculated (Nazreen et al., 2011).

Table 4: Weight of uterus of immature female rats treated with ethanolic leaves extract of Bambusa arundinaceae.

\begin{tabular}{lc}
\hline Treatment & Uterine weight $($ Mean \pm SEM) \\
\hline Control & $10.825 \pm 0.27$ \\
Standard $(0.2 \mathrm{mg} / \mathrm{kg}$ Ethinyl estradiol) & $17.01 \pm 0.29^{* * *}$ \\
Test $(200 \mathrm{mg} / \mathrm{kg})$ & $12.17 \pm 0.25^{*}$ \\
Test $(300 \mathrm{mg} / \mathrm{kg})$ & $13.81 \pm 0.44^{*}$ \\
Test $(400 \mathrm{mg} / \mathrm{kg})$ & $14.72 \pm 0.15^{* * *}$ \\
\hline Note: Means \pm Standard error mean $(\mathrm{SEM}) ;{ }^{*}$ significant at $\mathrm{p}<0.05$, \\
${ }^{* * *}$ significant at $p<0.01$.
\end{tabular}

Table 5: Weight of uterus of immature female rats treated with ethanolic fruits extract of Trichosanthes dioica.

\begin{tabular}{lc}
\hline Treatment & Uterine weight $($ Mean \pm SEM) \\
\hline Control & $10.825 \pm 0.276$ \\
Standard $(0.2 \mathrm{mg} / \mathrm{kg} \mathrm{CEE})$ & $16.683 \pm 0.481^{* * *}$ \\
Test $(200 \mathrm{mg} / \mathrm{kg})$ & $11.661 \pm 0.401^{\text {ns }}$ \\
Test $(300 \mathrm{mg} / \mathrm{kg})$ & $13.425 \pm 0.454^{*}$ \\
Test $(400 \mathrm{mg} / \mathrm{kg})$ & $12.715 \pm 0.45^{*}$ \\
\hline
\end{tabular}

Note: Means \pm Standard error mean (SEM); ${ }^{*}$ significant at $p<0.05$, *** significant at $p<0.01$.

Table 6: Weight of uterus of immature female rats treated with ethanolic seed extract of Punica granatum.

\begin{tabular}{lc}
\hline Treatment & Uterine weight (Mean \pm SEM) \\
\hline Control & $10.825 \pm 0.27$ \\
Standard $(0.2 \mathrm{mg} / \mathrm{kg} \mathrm{CEE})$ & $17.01 \pm 0.29^{* * *}$ \\
Test $(200 \mathrm{mg} / \mathrm{kg})$ & $12.55 \pm 0.44^{*}$ \\
Test $(300 \mathrm{mg} / \mathrm{kg})$ & $13.815 \pm 0.445^{\star}$ \\
Test $(400 \mathrm{mg} / \mathrm{kg})$ & $12.496 \pm 0.552^{*}$ \\
\hline
\end{tabular}

Note: Means \pm Standard error mean (SEM); ${ }^{*}$ significant at $p<0.05$, ${ }^{* * *}$ significant at $p<0.01$.

\section{RESULTS AND DISCUSSION}

The ethanolic extracts of the Bambusa arundinaceae, Punica granatum and Trichosanthes dioica respectively caused increase in the weight of uterus. The results (Table 4-6) showed the estrogenic effect of $B$. arundinaceae Punica granatum and Trichosanthes dioica when tested in immature ovariectomized rats. In the control animals weight of uterus was changed while the administration of standard dose of ethinyl estradiol) $(0.2 \mathrm{mg} / \mathrm{kg})$ resulted in the significant increase in weights of uterus. In comparison to the control group all the 3 plants extracts showed promising results Fig (1-3).

\section{Vaginal opening in female rats}

On analysis of the vaginal opening of the female rats it was found that with increasing days of treatment the vaginal opening dose dependently decreased (Table 7 ). In the standard group the opening was to the max at day 7 i.e. $80 \%$. The treatment of the extracts concised the muscles and resulted decrease in the vaginal opening (Fig 4a-8b).

\section{Histopathology studies}

The histopathology studies of Bambusa arundinaceae revealed promising results. In vaginal smear of ovariectomized rat from control group treated with normal saline for 7 days. A great number of leukocytes were observed (Fig 9). The Vaginal smear of immature rat treated with ethinyl estradiol $(0.2 \mathrm{mg} / \mathrm{kg})$ for 7 days cornified and nucleated epithelial cells were observed (Fig 10). The vaginal smear of immature rat treated with low dose (200 $\mathrm{mg} / \mathrm{kg}$ ) of Bambusa arundinaceae cornified, nucleated epithelial cells and leukocytes were observed (Fig 11). Vaginal smear of immature rat treated with medium dose (300 mg/kg) of Bambusa arundinaceae showed cornified, nucleated epithelial cells and leukocytes (Fig 12). The vaginal smear of ovariectomized rat treated with medium dose (400 mg/kg) of Bambusa arundinaceae cornified, nucleated epithelial cells and leukocytes are observed (Fig 13).

Administration of $B$. arundinaceae, Punica granatum and Trichosanthes dioica extract on immature ovariectomized

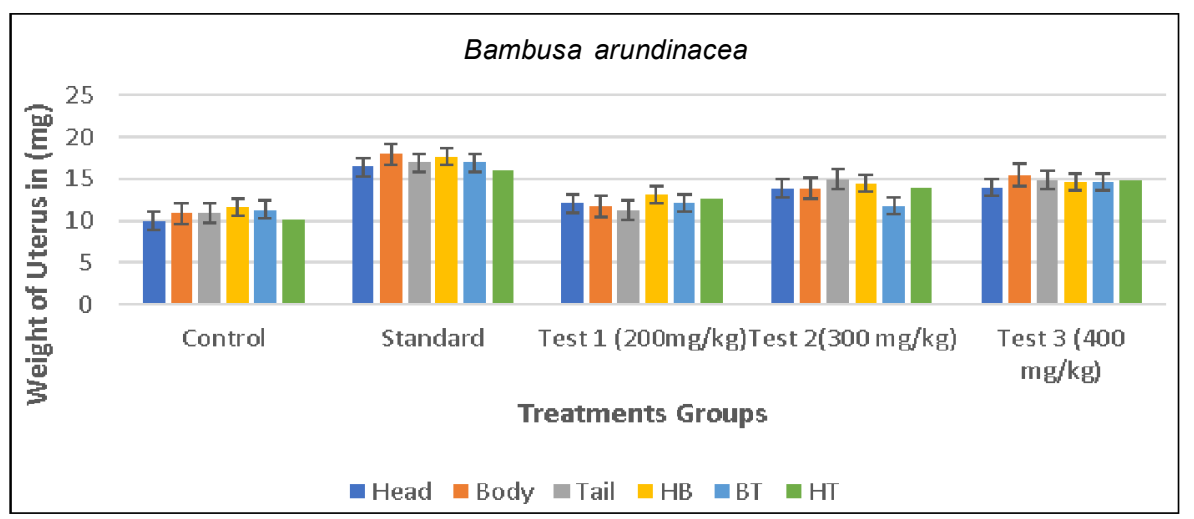

Fig 1: Effects of Bambusa arundinacea leaves ethanolic extract on immature female rats. The statistical significance of difference between means was calculated by Analysis of variance (ANOVA) followed by post hoc test for paired comparison. 
Estrogenic Effect of Bambusa arundinacea, Trichosanthes dioica and Punica granatum on Rats

rats results a significant increase of uterine weight. This might be due to the activation of estrogen responsiveness in the uterine wall. Another study found that uterine knockout mice showed significant results in terms of increasing of uterus after the application of estrogen due to estrogenic response in the immature uterus (Weihua et al. 2000). The bioactive molecules of the applied extract may have Estradiol-17 $\beta\left(\mathrm{E}_{2}\right)$ like flavonoides which are responsible for the significant effect on the vaginal opening, development of cornified epithelial cells and an increase of uterine wet

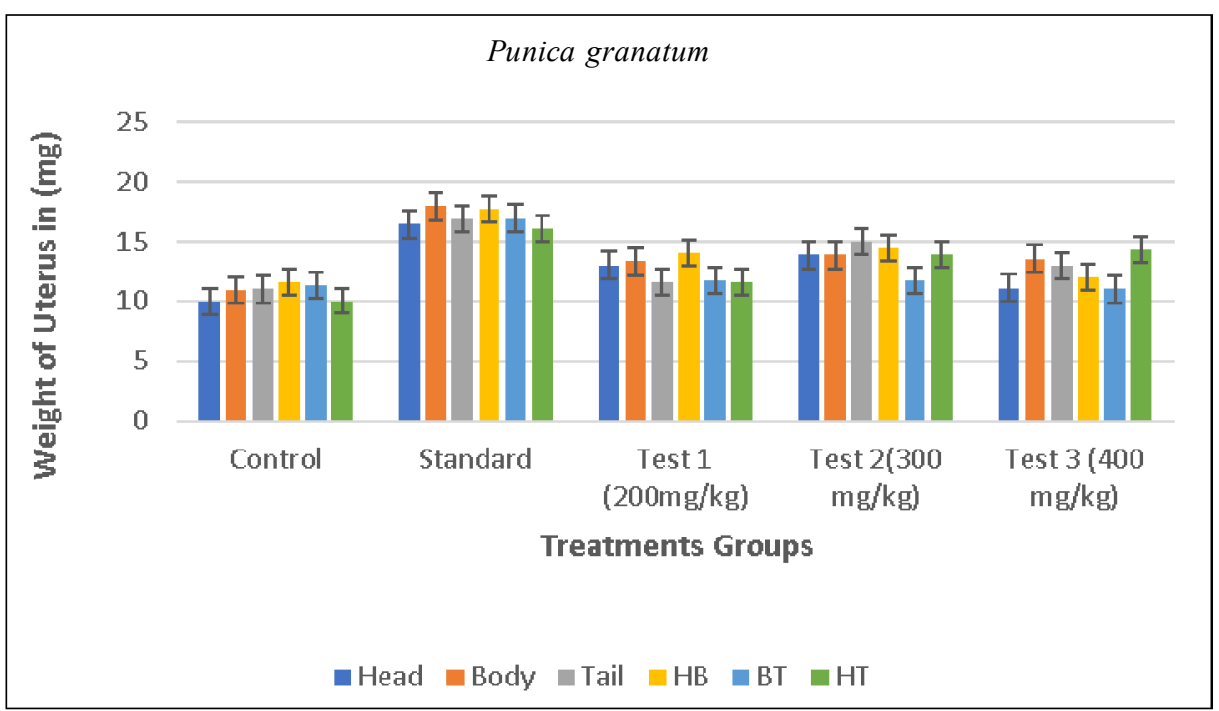

Fig 2: Effects of Punica granatum ethanolic extract on female rats. The statistical significance of difference between means was calculated by Analysis of variance (ANOVA) followed by post hoc test for paired comparison.

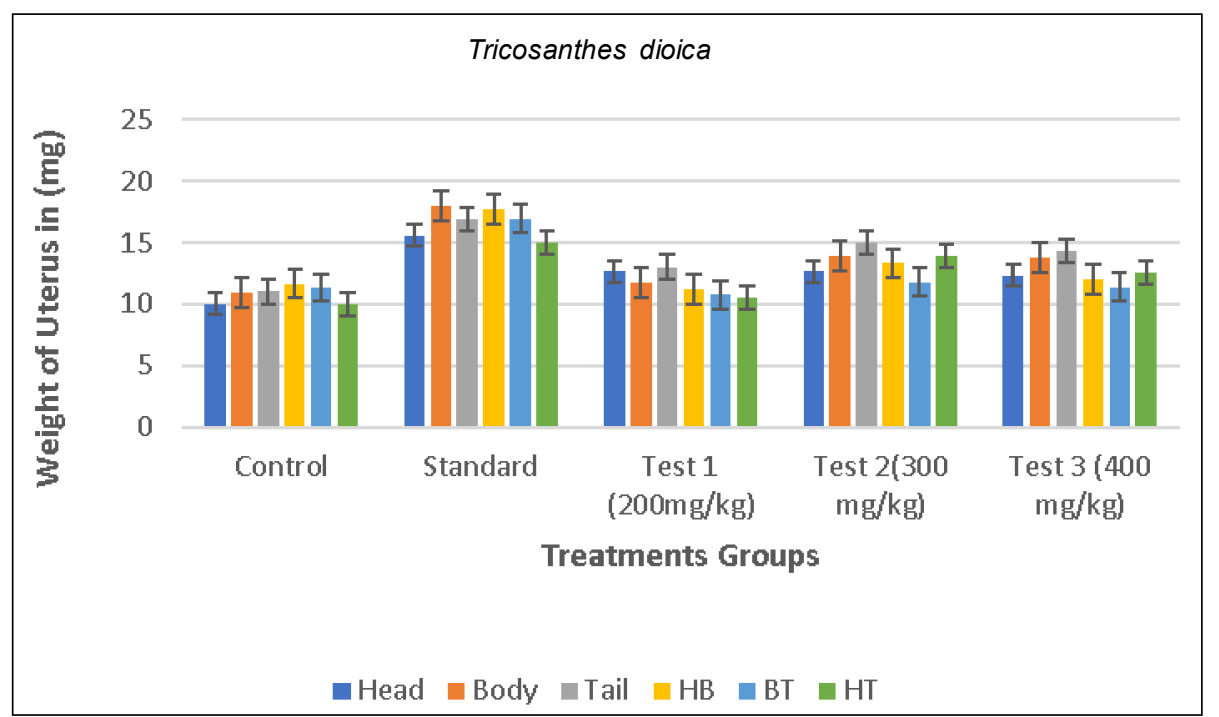

Fig 3: Effects of Tricosanthes dioica ethanolic extract on female rats. The statistical significance of difference between means was calculated by Analysis of variance (ANOVA) followed by post hoc test for paired comparison.

Table 7: Vaginal openings in the female rats.

\begin{tabular}{lccccccccc}
\hline \multirow{2}{*}{ Group } & \multirow{2}{*}{ Treatment } & Dose & \multicolumn{7}{c}{ Vaginal opening (\%) } \\
\cline { 6 - 10 } & & $(\mathrm{mg} / \mathrm{kg})$ & Day 1 & Day 2 & Day 3 & Day 4 & Day 5 & Day 6 & Day 7 \\
\hline Control (cmc) & 00 & 00 & 00 & 00 & 00 & 00 & 00 & 00 & 00 \\
Standard 0.2 mg/kg & 0.2 & 00 & 00 & 00 & 00 & 70 & 90 & 80 & 80 \\
Bambusa arundinaceae & 300 & 00 & 00 & 00 & 00 & 60 & 85 & 70 & 65 \\
Punica granatum & 300 & 00 & 00 & 00 & 00 & 40 & 55 & 60 & 45 \\
Trichosanthes dioica & 300 & 00 & 00 & 00 & 00 & 35 & 49 & 30 & 25 \\
\hline
\end{tabular}


Control group (cmc $10 \mathrm{mg} / \mathrm{kg})$

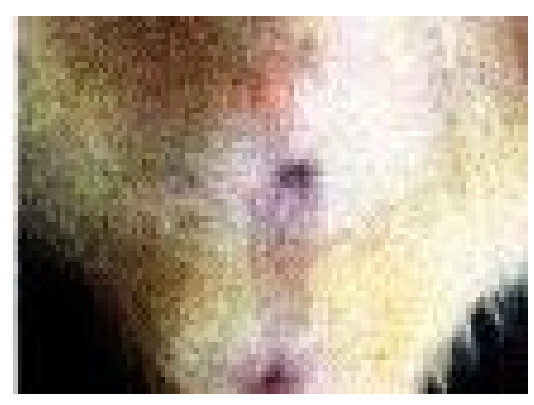

Fig $4 a$

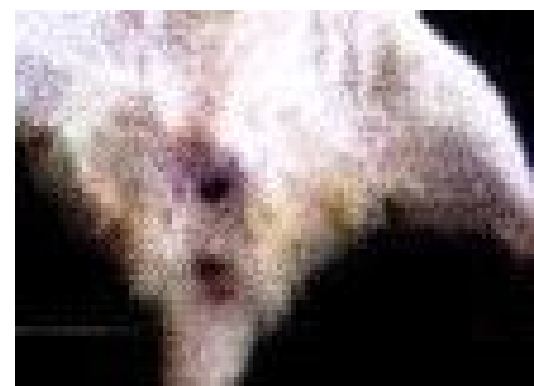

Fig $5 a$

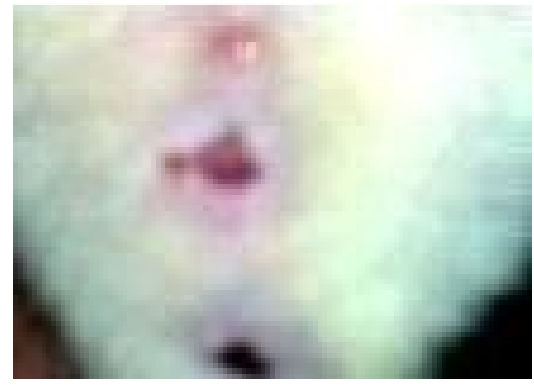

Fig 6a

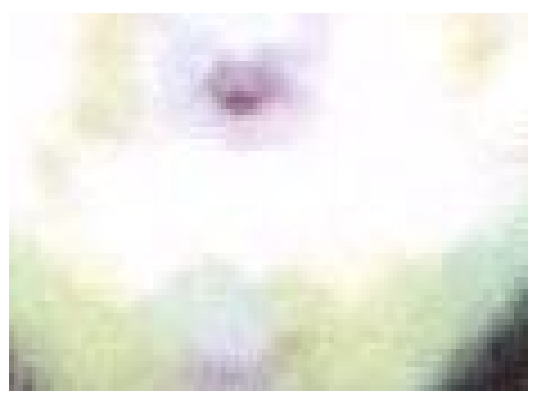

Fig $7 a$

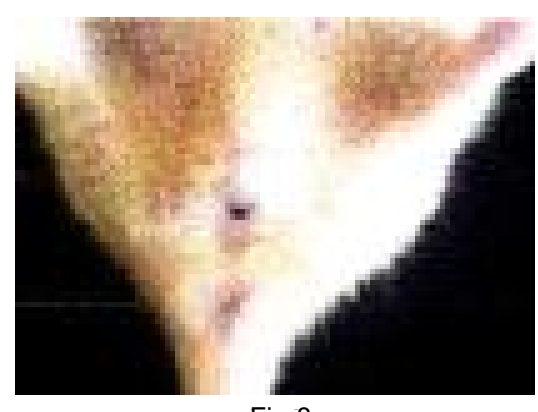

Fig $8 a$

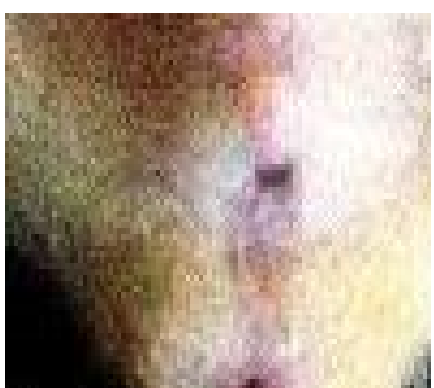

Fig $4 b$

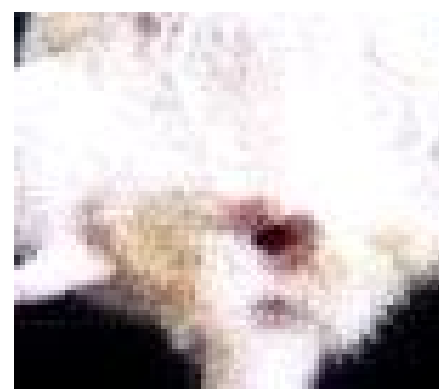

Fig $5 b$

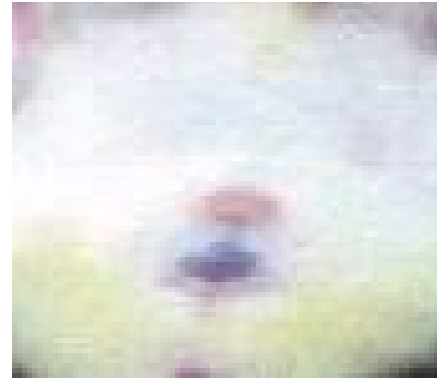

Fig $6 b$

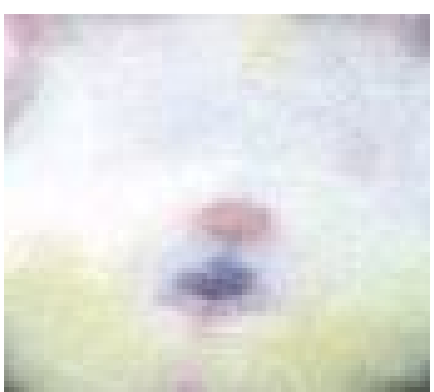

Fig $7 b$

Trichosanthes dioica (300 mg/kg)

Punica granatum $(300 \mathrm{mg} / \mathrm{kg})$

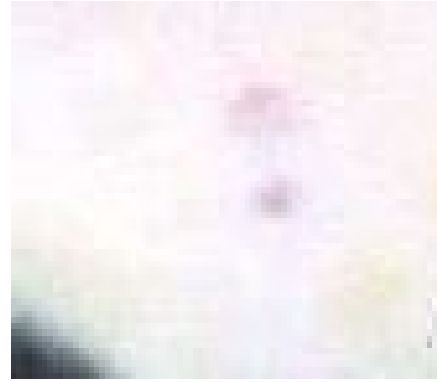

Fig $8 b$

Fig (4a-8b): The treatment of the extracts concised the muscles and resulted decrease in the vaginal opening. 
weight (Galand et al., 1971; Mäkelä et al., 1999). Therefore, these are the most probable reason for various effects of $B$. arundinaceae, Punica granatum and Trichosanthes dioica extract as phytoestrogens on reproductive organs of rats.

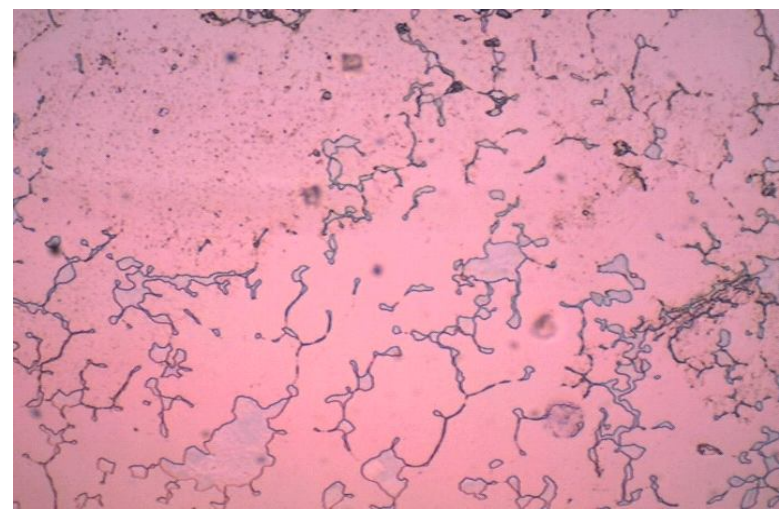

Fig 9: Vaginal smear of ovariectomized rat from control group treated with normal saline for 7 days. A great number of leukocytes were observed.

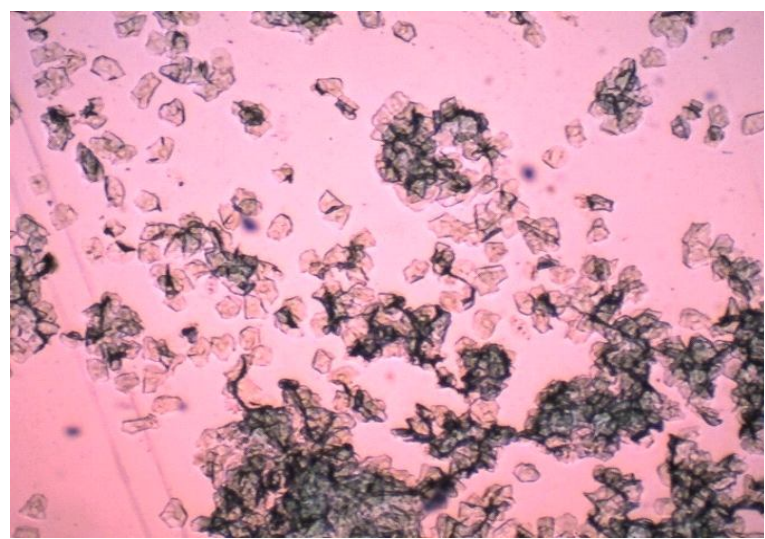

Fig 10: Vaginal smear of Immatured rat treated with Ethinyl Estradiol $(0.2 \mathrm{mg} / \mathrm{kg})$ for 7 days. Cornified and nucleated epithelial cells are observed.

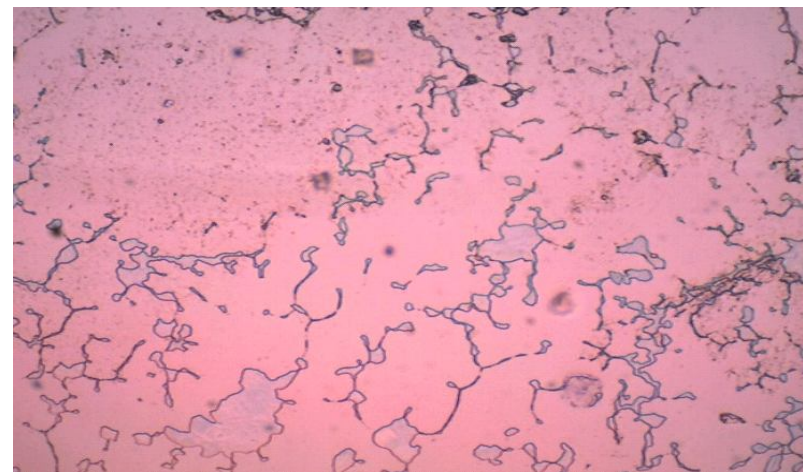

Fig 11: Vaginal smear of immature rat treated with low dose (200 $\mathrm{mg} / \mathrm{kg}$ ) of Bambusa arundinaceae cornified, nucleated epithelial cells and leukocytes are observed.

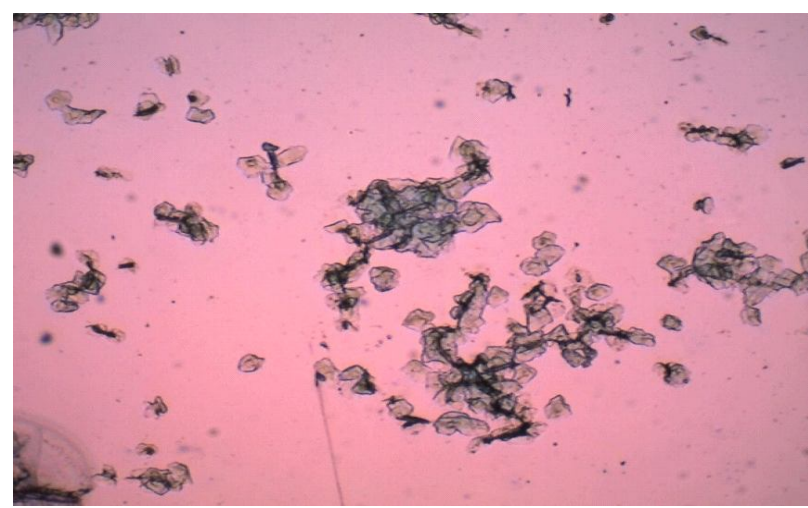

Fig 12: Vaginal smear of immature rat treated with medium dose (300 mg/kg) of Bambusa arundinaceae Cornified, nucleated epithelial cells and leukocytes are observed.

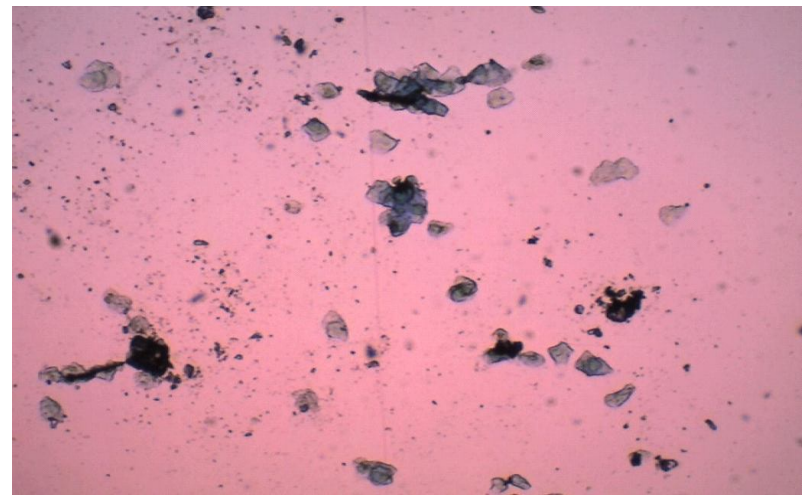

Fig 13: Vaginal smear of ovariectomized rat treated with medium dose $(400 \mathrm{mg} / \mathrm{kg}$ ) of Bambusa arundinaceae Cornified, nucleated epithelial cells and leukocytes are observed.

\section{CONCLUSION}

In this study, it was aimed to evaluate the estrogenic activity of ethanolic extract of Bambusa arundinaceae, Punica granatum and Trichosanthes dioica, respectively. The uterotropic assay showed the dose-related increase in uterine wet weight after administration of $200 \mathrm{mg} / \mathrm{kg}, 300$ $\mathrm{mg} / \mathrm{kg}$ and $400 \mathrm{mg} / \mathrm{kg}$ b.w., p.o. both in immature and mature ovariectomized rats. The ethanolic extract of Bambusa arundinaceae, Punica granatum and Trichosanthes dioica, respectively at higher dose (400 mg/kg b.w., p.o.) showed only cornified epithelial cells. The vaginal opening also showed that EBA (400 mg/kg b.w., p.o.) was having significant estrogenic activity. Thus, it can be concluded that the ethanolic extract of Bambusa arundinaceae, Trichosanthes dioica and Punica granatum play an important role in estrogenic activity in female rats.

\section{ACKNOWLEDGEMENT}

First author is highly grateful to Dr. Nisha Dutta and Dr. Avilekh Naryal, Department of Science and Pharmacology, for sharing their technical expertise. We are highly thankful to management of Vivek college of Technical Education, Bijnor, for the financial support to carry out this research work. 


\section{Conflict of Interest}

All authors declare that they have no conflict of interest.

\section{REFERENCES}

Bekoe, E.O., Kitcher, C., Debrah, P., Amoateng, P., Donkor, P.O. and Martinson, S. (2020). A Study on Phyllanthus amarus; Pharmacognostic, Mycobactericidal and Mutagenic Properties. Pharmacognosy Journal. 12(6s). https:// doi.org/10.5530/pj.2020.12.235.

Devi, S., Rashid, R. and Kumar, M. (2017). Phytochemistry and pharmacological properties of Phyllanthus amarus Schum: A review. Pharma Innov Journal. 6(12): 169-172.

Galand, P., Leroy, F. and Chretien, J. (1971). Effect of oestradiol on cell proliferation and histological changes in the uterus and vagina of mice. Journal of Endocrinology. 49(2): 243252. https://doi.org/10.1677/joe.0.0490243.

Goodman, L.S. and Parker, K. (2008). Goodman and Gilman's Manual of Pharmacology and Therapeutics. Mcgraw Hill Professional.

Khan, S., Rahman, M.M., Kabir, F., Nahar, K., Mamun, F., Lasker, S. and Haque, M.A. (2020). Trichosanthes dioica Roxb. prevents hepatic inflammation and fibrosis in CCl4-induced ovariectomized rats. Clinical Nutrition Experimental. 33: 1-17. https://doi.org/10.1016/j.yclnex.2020.07.001.

Khatua, S., Pandey, A. and Biswas, S.J. (2016). Phytochemical evaluation and antimicrobial properties of Trichosanthes dioica root extract. Journal of Pharmacognosy and Phytochemistry. 5(5): 410.

Kumar, H.K., Raju, M.B.V., Dinda, S.C. and Sahu, S. (2012). Evaluation of anthelmintic activity of Bambusa arundinaceae. Asian Journal of Pharmacy and Technology. 2(2): 62-63.

Kumar, N., Singh, S. and Manvi, R.G. (2012). Trichosanthes dioica Roxb.: an overview. Pharmacognosy Reviews. 6(11): 61. https://doi.org/10.4103/0973-7847.95886

Mäkelä, S., Savolainen, H., Aavik, E., Myllärniemi, M., Strauss, L., Taskinen, E. and Häyry, P. (1999). Differentiation between vasculoprotective and uterotrophic effects of ligands with different binding affinities to estrogen receptors $\alpha$ and $\beta$. Proceedings of the National Academy of Sciences. 96(12): 7077-7082. https://doi.org/10.1073/pnas. 96.12.7077.

Malaivijitnond, S., Chansri, K., Kijkuokul, P., Urasopon, N. and Cherdshewasart, W. (2006). Using vaginal cytology to assess the estrogenic activity of phytoestrogen-rich herb. Journal of Ethnopharmacology. 107(3): 354-360. https://doi.org/10.1016/j.jep.2006.03.026

Mertens-Talcott, S.U., Jilma-Stohlawetz, P., Rios, J., Hingorani, L. and Derendorf, H. (2006). Absorption, metabolism and antioxidant effects of pomegranate (Punica granatum L.) polyphenols after ingestion of a standardized extract in healthy human volunteers. Journal of Agricultural and Food Chemistry. 54(23): 8956-8961. https://doi.org/ 10.1021/jf061674h.
Nazreen, S., Alam, M.S., Hamid, H., Kaur, G., Alam, M.M., Haider, S. and Shafi, S. (2011). Phytochemical investigation of Bam Bambusa arundinaceae Retz. Internationl Journal of Natura I Product Science. 3: 1-7.

Nilsson, S., Makela, S., Treuter, E., Tujague, M., Thomsen, J. Andersson, G. et al. (2001). Mechanisms of estrogen action. Physiological Reviews. 81(4): 1535-1565. https:/ /doi.org/10.1152/physrev.2001.81.4.1535.

Parhizkarsup, S., Latiffsup, L.A., Rahmansup, S.A., Dollahsup, M.A. and Parichehr, H. (2011). Assessing estrogenic activity of Nigella sativa in ovariectomized rats using vaginal cornification assay. African Journal of Pharmacy and Pharmacology. 5(2): 137-142. https://doi.org/10.5897/ ajpp10.276.

Peters, H. and McNatty, K.P. (1980). The ovary: A correlation of structure and function in mammals. Univ of California Press.

Procházková, T., Sychrová, E., Javùrková, B., Veèerková, J., Kohoutek, J., Lepšová-Skácelová, O. et al. (2017). Phytoestrogens and sterols in waters with cyanobacterial blooms-Analytical methods and estrogenic potencies. Chemosphere. 170: 104-112. https://doi.org/10.1016/j. chemosphere.2016. 12.006.

Sharangouda, S. and Patil, S.B. (2008). Estrogenic activity of petroleum ether extract of seeds of Citrus medica on immature albino rats. International Journal of Green Pharmacy. 2(2). https://doi.org/10.4103/0973-8258.41178.

Sreeja, S., Kumar, T.R.S., Lakshmi, B.S. and Sreeja, S. (2012). Pomegranate extract demonstrate a selective estrogen receptor modulator profile in human tumor cell lines and in vivo models of estrogen deprivation. The Journal of Nutritional Biochemistry. 23(7): 725-732. https://doi.org/ 10.1016/j.jnutbio.2011.03.015.

Tripathi, Y.C., Kaushik, P.K. and Bhuyan, T.C. (2013). Sustainable development of quality bamboo resource for employment generation and socio-economic development in NE India. Jorhat: Rain Forest Research Institute. 11-13.

Valadares, M.C., Pereira, E.R.T., Benfica, P.L. and Paula, J.R. (2010). Assessment of mutagenic and antimutagenic effects of Punica granatum in mice. Brazilian Journal of Pharmaceutical Sciences. 46: 121-127. https://doi.org/10.1590/S198482502010000100014.

Wardhani, D.H., Yuliana, A.E. and Dewi, A.S. (2016). Natrium Metabisulfit sebagai Anti-Browning Agent pada Pencoklatan Enzimatik Rebung Ori (Bambusa arundinaceae). Journal Aplikasi Teknologi Pangan. 5(4).

Weihua, Z., Saji, S., Mäkinen, S., Cheng, G., Jensen, E.V., Warner, M. and Gustafsson, J.A. (2000). Estrogen receptor (ER) beta, a modulator of ERalpha in the uterus. Proceedings of the National Academy of Sciences of the United States of America. 97(11): 5936-5941. https://doi.org/10.1073/ pnas.97.11.5936 